\title{
The Main Aspects of the Activities of Charitable Organizations in the Legacy of Mary Ellen Richmond
}

\author{
Petrukhan-Scherbakova Liudmyla \\ Lecturer at the Department of Theory and History of Pedagogy \\ Borys Grinchenko Kyiv University
}

Chernukha Nadiia

Doctor of Pedagogical Sciences, Professor

Taras Shevchenko National University (Kyiv, Ukraine)

\begin{abstract}
The article is devoted to the analysis of the scientific heritage of Mery Elen Richmond. A cornerstone of building the social work profession, Mary Richmond was known for her ability to organize communities, her development of casework practice, as well as her ability to teach and speak intelligently on a wide array of subjects.

The subject of the article is the provisions on the activities of charitable organizations in the United States during the life and work of the researcher. The article describes the main problems in the activities of charitable organizations of the late 19th - early 20th centuries During this time Richmond was connected to the COS, she demonstrated her qualities as a leader, teacher, and practical theorist; ; revealed the functions of charitable organizations in the theory and practice of M. E. Richmond; described possible provisions for improving the activities of charitable organizations in accordance with the legacy of Mary Ellen Richmond, who is considered a principle founder of the profession of social work and the importance of professional education.

Her first principle was that care had to focus on the person within their situation. Building on extensive research, she developed what she labelled 'social diagnosis'. Her famous circle diagram visualized the correspondence of client and environment. Richmond identified six sources of power that are available to clients and their social workers: sources within the household, in the person of the client, in the neighborhood and wider social network, in civil agencies, in private and public agencies. This is a precursor of the system theory that was so popular in 1970's social work.
\end{abstract}

Key words: charitable activities, charitable organization, social work, Mary Ellen Richmond.

Актуальність дослідження. Україна знаходиться в дуже стресовому історичному періоді. Коли з одного боку в усьому світі йде переформатування державної політики в умовах пандемії й майбутньої фінансової кризи, з іншого - наявність суто українських питань: бойові дії на території України та окупований Крим; процеси децентралізації. Як результат, перед соціальною політикою України постали нові виклики. Серед яких наступні питання: ресоціалізація осіб, що мають статус вимушених переселенців; психологічна допомога та ресоціалізація учасників бойових дій та їх родин; допомога родинам, які потрапили в кризові ситуації (і кількість таких родин щомісяця збільшується). В таких умовах недержавні об'єднання активно беруть на себе гуманітарну місію і допомагають населенню. Найбільш активними в такій кризовій 
ситуації виступають благодійні організації. На наш погляд, в таких умовах корисними $є$ наукові надбання зарубіжних науковців, чиї доробки можуть бути актуалізовані i адаптовані до сучасних українських реалій. Тому особливо цікавим виступає наукова та емпірична спадщина Мері Елен Річмонд, засновниці social case work (соціальна робота в ситуації або ведення випадку) та авторки наукових доробків, що розкривають специфіку роботи благодійних організацій та соціальної роботи в Америці.

Відповідно до означеного мета статті полягає у дослідженні спадщини Мері Елен Річмонд для формування основних компонентів діяльності благодійних організацій з подальшою метою актуалізації в сучасних українських реаліях. Для реалізації мети були сформовані наступні задачі статті: розглянути основні праці М. Е. Річмонд; сформувати основні позиції по діяльності благодійних організацій; описати можливі шляхи реалізації ідей в сучасній Україні.

Виклад основного матеріалу. Відповідно до українського законодавства благодійна організація визначається як «юридична особа приватного права, установчі документи якої визначають благодійну діяльність в одній або декількох сферах, визначених законом, як основну мету ії діяльності» [4]. На 1 жовтня 2020 р. в Україні зареєстровано 19625 благодійних організацій різного типу [1], що майже на тисячу організацій більше порівнюючи із минулим роком.

Вивченням діяльності та станом справ благодійних організацій в Україні займаються Л. Бідний, Д. Горєлов, В. Згурська, Г. Загорій, А. Зінченко, Н. Пеліванова, Т. Полонець, В. Родченко, М. Саприкіна В. Сичова та ін. Можливість впровадження зарубіжного досвіду в українську практику розглядають О. Безпалько, В. Давилюк, I. Завидняк, І. Звєрєва, О. Пилипенко, М. Строгаль, Н. Чернуха та ін. Ці дослідження та наукові доробки акцентують увагу більше на питаннях правового регулювання та фінансової діяльності благодійних організацій. Певного комплексного аналізу досвіду і теорій персоналій та пропозицій в процесі підготовки статті нами не було виявлено. В процесі аналізу робіт «What is social case work? An introductory description», «Social Diagnosis», «The Good Neighbor», «Friendly visiting among the poor. A Handbook for Charity Workers», «. A study of nine hundred and eighty-five widows», «The long view. Papers and addresses. by Mary E. Richmond» нами було окреслено наступні позиції [6; 7; 8; 9; 10; 11$]$. 
По-перше. В проаналізованих роботах сформовано опис функцій виконувані благодійними організаціями: 1) надання соціального працівника у супровід для вирішення складної ситуації клієнта; 2) надання матеріальної допомоги; 3) проведення дослідження та експертизи і формування звітів стосовно стану тієї чи іншої категорії населення; 4) включення в робочі групи 3 корекції законодавства, розробки та провадження реформ; 5) організація навчання фахівців соціальної сфери; 6) публікаціця корисних матеріалів та результатів проведених досліджень;7) посередництво між державними структурами та клієнтом; 8) консультація промислових підприємств різних масштабів щодо роботи із співробітниками; 9) долучення до практичного регулювання соціальних стосунків.

По-друге. Проведені Мері Елен Річмонд дослідження, дозволили виокремити групу проблемних питань, пов’язаних із діяльністю благодійних організацій. Ці проблеми були класифіковані за наступними категоріями:

А). Проблеми, що стосуються кадрового складу благодійних організацій: 1) наявний різний рівень кваліфікації соціальних працівників і працівників фондів; 2) наявність у складі соціальних працівників неоднорідностей (із різним рівнем досвіду, теоретичною та практичною підготовкою; фінансовим достатком родини; мала кількість жінок в управліннях благодійних структур та чоловіків в полі тощо); 3) обіймання керівних посад в благодійних організаціях осіб, які не займаються системно планом їх роботи або не розуміють куди має рухатися організація; 4) наявність серед соціальних працівників новачків, які вважають, що можливо всі проблеми вирішувати швидко із залученням спеціалізованих закладів виправного характеру, замість системної роботи із мисленням клієнта, яка є довготривалою.

Б). Проблеми, що стосуються внутрішньо організаційного розвитку та діяльності благодійних організацій: 1) фінансування благодійних об’єднань. Під цим, у своєму виступі «Criticism and reform in charity» Мері Річмонд [11, с. 46-50] наголошувала на помірне фінансування благодійних фондів їх засновниками. Адже забагате фінансування вбивало креативний підхід і винахідливість соціальних працівників, а замале змушувало соціальних працівниць шукати нові місця роботи, що спричиняло плин кадрів. Дуже добре, коли благодійна організація мала фінансування для оплати працівників, адже це дозволяло зберігати кадри; 2) наявність / відсутність інших типів 
ресурсів в організації; 3) наявність / відстуність плану розвитку організацій; 4) не системна робота з волонтерами та соціальними працівниками благодійних фондів.

В). Проблеми, що стосуються надання послуг / допомоги клієнтам: 1) надання благодійними структурами допомоги на рівних, не враховуючи специфіку клієнтів (комусь треба більше, а комусь у меншій кількості ніж дає організація); 2) акцент на матеріальній допомозі нужденним; 3) настороженість та недовіра клієнта при проведенні соціальним працівником оцінки кризової ситуації; 4) помилкове визначення в оцінці кризової ситуації при неповному аналізі і розкритті всіх сфер.

Г). Проблеми зовнішнього характеру (пов'язані із суспільством та державою): 1) відсутність сприйняття клієнта та його родини як єдине ціле кількома фахівцями різних форм благодійної діяльності, які одночасно допомагають (наприклад, викладач недільної школи, менеджер ясел, агент милосердя, окружна медсестра, акушерська медсестра, церковний працівник сфери соціального обслуговування, міської місіонер, допоміжний агент, голова зустрічей матерів, викладач гільдії й інші, - всі вони торкнуться сім'ї в певний момент, але ніколи не подбає про зображення сімейного життя в цілому» [7, с. 45]. Це призвело до того, що при засіданнях, де вирішувалися питання чоловіка і дружини інтереси дітей не були враховані і навпаки, при обговоренні справ дитини як учня забувалось про його участь в домашньому господарстві; 2) наявність в містах благодійних організацій, що не задовольняють жодної реальної потреби в громаді; 3) проблема гласності і допомоги (коли одна частина суспільства вважала, що якщо надавати гласність кризовій ситуації певної особи, то це пришвидшить фінансові вливання для її вирішення). Натомість більшість осіб, що знаходяться в кризовій ситуації хочуть навпаки знаходитися в тіні і все залишити приватним; 4) проблема законодавчого регулювання діяльності організацій.

Питання ефективності соціальної роботи та діяльності благодійних організацій у спадщині Мері Елен Річмонд розкрито нами в статті «Теоретичні підходи до поняття «ефективність соціальної роботи» в спадщині Мері Елен Річмонд [2], тому ми не зупинятимемося на цьому детально.

По-третє. Науковий аналіз робіт М. Е. Річмонд дозволив виокремити перелік рекомендацій щодо покращення роботи благодійних організацій, що призвело для розвитку соціальної сфери в Америці. Одним із ключових положень теорії соціальної 
роботи американки Мері Елен Річмонд стосовно діяльності благодійних організацій є важливість наявності зв'язку та обміну інформацією між благодійними [6, с. 27-28, 45]. Такий зв'язок має формуватися на етичних принципах соціальної роботи, таких як довіра, відповідальність, анонімність.

Зауваження і побажання щодо роботи працівників благодійних організацій, висловлені Мері Елен Річмонд: 1) урахування ким є соціальний працівник, адже особа 3 бідної сфери, яка розуміє ситуацію клієнта, але, нажаль, має недостатню кількість фахових знань, інколи це навпаки шкодить, адже соціальний працівник занадто співпереживає і жаліє; 2) має бути налагоджена робота із особами, що мають хороший фінансовий стан, а благодійність це їх покликання душі; 3) співробітники мають володіти фаховими знаннями і мати відповідну освіту; 4) врахування в роботі наявності у складі соціальних працівників з різним рівнем підготовки; 5) нагадувати працівнику, про має пам'ятати про свою кінцеву мету роботи.

Наступним положенням теорії М. Е. Річмонд є важливість врахування в роботі таких етичних принципів: 1) допомогу потрібно надавати індивідуально і конфіденційно; 2) голова сім'ї має бути активно включений і стати активним учасником на всіх рівнях і у всіх питаннях щодо вирішення проблемної ситуації та надання допомоги; 3) для вирішення ситуації клієнта соціальний працівник і працівник благодійної організації має активізувати оточуюче клієнта середовище; 4) при прийнятті рішення давати або відмовляти в допомозі, соціальні працівники мають керуватися його ймовірним впливом на майбутнє претендента. Увага звертається на форму допомоги i план іiі використання, адже будь яка допомога може без плану реалізації нашкодити; 5) замість того, щоб намагатися надати допомогу по трохи багатьом нужденним, благодійні організації повинні допомогти максимально тим, хто цього потребує найбільше; 6) форма допомоги може бути різною (знання, матеріальна, контакти, увага та ін.); 7) форма допомоги повинна змінюватися відповідно до індивідуальних обставин і потреб клієнта. Соціальні працівники мають знайти ту форму допомоги яка буде найкращим методом у вирішенні кризової ситуації та закритті специфічної потреби; 8) працівники благодійних організацій так само як і соціальні працівники з часом мають зменшувати рівень включеності соціального працівника в життя клієнта. Цей принцип виведений нами на основі робіт Мері Елен Річмонд, показує, що основною метою 
соціального працівника в роботі 3 клієнтом навчити останнього самостійності i відповідальності за власне життя, що дозволить не тільки вийти із даної кризової ситуації, а не потрапити до неї знову.

Отже, зазначені вище пункти як були актуальні в період життя і роботи Мері Елен Річмонд, лишаються і сьогодні, хоча принципи і були впроваджені в кодексі соціального працівника і використовуються в усьому світі.

Висновки. Зважаючи на викладене, можна дійти висновку про те, що основи соціальної роботи та діяльності благодійних організацій, які описала в своїх роботах Мері Елен Річмонд $є$ актуальними і по сьогодні. Дослідження проблем сучасних благодійних організацій потребує додаткового аналізу і має бути висвітлено в окремій статті. При цьому із впевненістю зазначаємо, що діяльність фахівців сучасних благодійних організацій можливо покращити за умови використання рекомендацій сформованих нами на основі аналізу робіт Мері Елен Річмонд.

\section{References}

1. Kilkist yurydychnykh osib za orhanizatsiyno-pravovymy formamy hospodaryuvannya. Sait Derzhstatystyky Ukrayiny [Number of legal entities by organizational and legal forms of management. Website of the State Statistics of Ukraine].

URI : http://www.ukrstat.gov.ua/edrpoy/ukr/EDRPU_2020/ks_opfg/ks_opfg_1020.htm

2. Petrukhan-Shcherbakova L. Teoretychni pidkhody do ponyattya «efektyvnist sotsialnoyi roboty" v spadshchyni Mery Elen Richmond [Theoretical approaches to the concept of "efficiency of social work" in the legacy of Mary Ellen Richmond]. Neperervna profesiyna osvita: Teoriya i praktyka. 2018. № 1-2.Pp. 108-113. DOI: https://doi.org/10.28925/16098595.2018(1-2)108113

3. Petko L.V. Vykhovnyi potentsial metodu sytuatsiinoho analizu ("Case study» method) $u$ formuvanni profesiino oriientovanoho inshomovnoho navchalnoho seredovyshcha $v$ umovakh universytetu [Educational potential of the «Case study» method for the forming of the professionally oriented foreign language teaching environment in the conditions of university]. Naukovyi chasopys NPU imeni M.D.Drahomanova. Seriia 17. Teoriia i praktyka navchannia ta vykhovannia: zb. nauk. pr. ; za red. akademika V.I.Bondaria. Kyiv: Vyd-vo NPU imeni M.P.Drahomanova, 2015. Issue 27. P. 133-140.

4. Pro blahodiynu diyal'nist' ta blahodiyni orhanizatsiyi: Zakon Ukrayiny [On charitable activities and charitable organizations: Law of Ukraine]. URI : https://zakon.rada.gov.ua/laws/show/5073-17\#Text

5. Chernukha N.M., Aslanov G. Sotsialni komunikatsii v interkulturnomu prostori: vidpovid na vyklyky sohodennia [Social communications in the intercultural space: a response to the challenges of today] // Innovative processes in education: Collective monograph. AMEET Sp. z o.o., Lodz, Poland, 2017. P. 230-237. 
6. Richmond Mary E. A study of nine hundred and eighty five widows. Known to certain charity organization societies in 1910. New York City: Charity Organization Dept of the Russell Sage Foundation. 1913. 83 p.

7. Richmond Mary E. Friendly Visiting among the Poor. A Handbook for Charity Workers. - New York The MacMillan Company London: MacMillan \& Co., Ltd. 1907/ All rights reserved/ Copyright, 1899, by The MacMillan Company. Set up and electrotyped January, 1899. Reprinted November, 1899; February, 1903; February, 1906; November, 1907. 219 p. Press Stable

URL: https://archive.org/details/friendlyvisiting00richrich/page/n1/mode/2up

8. Richmond, Mary E. Social Diagnosis. - New York: Russell Sage Foundation, 1917. No 1.487 p.

9. Richmond, Mary E. The good neighbor in the modern city.1908. 152 p.

10. Richmond, Mary E. Social work series. What is social case work? An introductory description. New York : RUSSELL SAGE FOUNDATION, 1915, 1922.

11. The long view. Papers and addresses. by Mary E. Richmond. selected and edited with biographical notes by Joanna C. Colcord, Director of the charity organization department, Russell sage foundation; and Ruth Z. S. Mann. - New York, Russell Sage Foundation. 1930. 165 p.

Translation of the Title, Abstract and References to the Author's Language

\section{УДК 378:37:37:013.42}

Петрухан-Щербакова Людмила, Чернуха Надія. Основні аспекти діяльності благодійних організацій у спадщині Мері Елен Річмонд.

Статтю присвячено аналізу наукової і практичної спадщини Мер Елен Річмонд. Предметом дослідження статті стали положення, присвячені діяльності благодійних організацій у Сполучених Штатах Америки в період життя та роботи американської дослідниці. Описано основні проблеми в діяльності благодійних організацій кіния XIXпочатку XX століття; розкрито функиії діяльності благодійних організацій періоду життя М. Е. Річмонд; охарактеризовано можливі напрямки для покращення діяльності благодійних організацій відповідно до спадщини Мері Елен Річмонд. Стаття буде иікава викладачам, які займаються підготовкою сочіальних працівників та сочіальних педагогів.

Ключові слова: благодійна діяльність, благодійна організація, соціальна робота, Мері Елен Річмонд.

\section{Література}

1. Кількість юридичних осіб за організаційно-правовими формами господарювання. Сайт Держстатистики України. URL : http://www.ukrstat.gov.ua/edrpoy/ukr/EDRPU_2020/ks_opfg/ks_opfg_1020.htm

2. Петрухан-Щербакова Л. Теоретичні підходи до поняття «ефективність соціальної роботи» в спадщині Мері Елен Річмонд. Неперервна професійна освіта: 
Теорія $і$ практика. 2018. № 1-2. C. 108-113. DOI : https://doi.org/10.28925/1609$8595.2018(1-2) 108113$

3. Петько Л. В. Виховний потенціал методу ситуаційного аналізу («Case study» method) у формуванні професійно орієнтованого іншомовного навчального середовища в умовах університету. Науковий часопис НПУ імені М.Д.Драгоманова. Серія 17. Теорія і практика навчання та виховання : зб. наук. пр. ; за ред. академіка В.І.Бондаря. Київ : Вид-во НПУ імені М.П.Драгоманова, 2015. Вип. 27. С. 133-140.

4. Про благодійну діяльність та благодійні організації: Закон України. URI : https://zakon.rada.gov.ua/laws/show/5073-17\#Text

5. Чернуха Н.М. Соціальні комунікації в інтеркультурному просторі: відповідь на виклики сьогодення / Н.М.Чернуха, Г.Асланов // Innovative processes in education: Collective monograph. - AMEET Sp. z o.o., Lodz, Poland, 2017. - P. 230-237.

6. Richmond, Mary E. A study of nine hundred and eighty five widows. Known to certain charity organization societies in 1910. New York City: Charity Organization Dept of the Russell Sage Foundation. 1913. 83 p.

7. Richmond, Mary E. Friendly Visiting among the Poor. A Handbook for Charity Workers. New York The MacMillan Company London: MacMillan \& Co., Ltd. 1907/ All rights reserved/ Copyright, 1899, by The MacMillan Company. Set up and electrotyped January, 1899. Reprinted November, 1899; February, 1903; February, 1906; November, 1907. 219 p. Press Stable URL : https://archive.org/details/friendlyvisiting00richrich/page/n1/mode/2up $487 \mathrm{p}$.

8. Richmond, Mary E. Social Diagnosis. New York : Russell Sage Foundation. 1917. No 1.

9. Richmond, Mary E. The good neighbor in the modern city 1908. $152 \mathrm{p}$.

10. Richmond, Mary E. Social work series. What is social case work? An introductory description. - New York : Russell Sage Foundation. 1915, 1922.

11. The long view. Papers and addresses. by Mary E. Richmond. selected and edited with biographical notes by Joanna C. Colcord, Director of the charity organization department, Russell sage foundation; and Ruth Z. S. Mann. New York : Russell Sage Foundation. 1930. $165 \mathrm{p}$. 